\title{
Respondent's Perception on Demographic and Socio-economic Characteristics of Ikogosi Warm Spring for Environmental Sustainability
}

\author{
Olowookere-Ayodele ${ }^{1, *}$, Olusayo Oluwakemi ${ }^{1}$, Ayeni Ayodele Olaiya ${ }^{2}$, Imole Patrick Olaniyi ${ }^{3}$ \\ ${ }^{1}$ Department of Tourism and Hospitality Management, Ekiti State University, Nigeria \\ ${ }^{2}$ Home Economics Department, College of Education, Nigeria \\ ${ }^{3}$ Ekiti State University, Ado Ekiti, Nigeria
}

Copyright $\mathrm{O} 2018$ by authors, all rights reserved. Authors agree that this article remains permanently open access under the terms of the Creative Commons Attribution License 4.0 International License

\begin{abstract}
Perception is an agent's subjective experiential evaluation of the phenomenal which surrounds man, revealing his consciousness of it and his intentionality towards the object which constitute it. Primary data were collected with the aid of structured questionnaire from the host community with 300 respondents' sample size. Information was sought pertaining to the demographic characteristics of the respondents and the impacts of the tourist attraction on the host community both the positive and the negative aspects respectively. Questionnaire were distributed through random sampling based on availability by rating their level of agreement with each of the statement on a five-point Likert's scale from strongly agree (SA), agree (A), undecided (U), Disagree (D) and strongly disagree (SD). Data were analyzed and tested using descriptive and inferential statistical techniques, independent sample t- test and one-way ANOVA test at $p<0.05$. The ANOVA analysis indicates that there is no significant variation in people's perceptions of the negative impacts of the tourist attraction on the demographic characteristics except educational qualification that shows significant variation in people's perception while test on people's perceptions of the positive impacts of the tourist attraction demographic characteristics shows that there is no significant variation in people's perception impacts of the tourist attraction on the host community and the independent sample t-test for both negative and positive impacts also shows that there is no significant variation in people's perception. Therefore, the tourism impacts can there be categories into three parts namely socio-cultural impact, economic impact and environmental impact with lists numbers of multiplier effects of tourism such as job creation, increasing income of local economy, boosting local business, generating other industrial activities in the town, social event in the community, better local facilities and infrastructure, conservation of the natural endowment and attractive environment appeals to tourists. The host community of any tourist attractions must have
\end{abstract}

rightful perception of the development as sustainability of tourism industry left nobody out, in developing the tourist attraction.

Keywords Perception, Ikogosi, Respondent, Environment and Sustainability

\section{Introduction}

The perception of the host community's towards the development of tourism is very essential because tourism is one of the major strategies for development as addressed by World Tourism Day[29], to draw attention to the role of tourism in contributing to one of the building blocks of a more sustainable future for all community development. The world leaders in tourism sector have recently launched a new international programme that will focus more on sustainable tourism over the next decade, World travel market [30], London. World Tourism Organisation (UNWTO) of the United Nations identifies tourism industry as one of the largest economic sectors in the world accounting for $9 \%$ of global GDP; one in eleven jobs; as a key revenue sector for developing and emerging economies in the communities.

According to Green Economy Report published by UNEP; Anana[4], a business-as-usual, scenario, projected tourism growth rates to 2050 will result in increases in energy consumption by $154 \%$, greenhouse gas emissions by $131 \%$, water consumption by $152 \%$ and solid waste disposal by $251 \%$. The consolidation of tourism's economic influence has built up its social responsibility and political relevance, with a growing number of countries allocating a stronger mandate to tourism in economic and development policy planning with special focus on the community. Choi; Benson; WTD [29] identified how tourism can be conducive to advancing sustainable development from the grassroots level. 
Community based tourism involves the local population in the decision making process according to local priorities. The opportunity to become part of the tourism value chain actively involves the communities in the development process. Tourism thus becomes a catalyst of social cohesion, going beyond the immediate impact of job creation and its positive economic consequences and enhances WTD [29].

The rapid and steady growth of the tourism industry has meant that many governments are recognizing the significant of tourism and are looking towards the benefits the industry can bring and indeed, as a constant contributor to economies worldwide, tourism influences global scale needs to be acknowledged, the Guardian Newspaper[14]. The international tourism industry has become a global economic force, generating significant revenues and contributing directly and indirectly to national economics. The World Tourism Organization [34] indicated that 703 million tourists traveled across international boundaries, generating over US\$ 474 billion in revenues. In its tourism growth forecasted, Tourism: 2020 vision, the WTO also predicts that the tourism sector will grow by an average of $4.1 \%$ per year over the next two decades, surpassing a total of 13 billion international tourists by the year 2010. Projections for the year 2020 indicated that tourist arrivals will grow to around 1.6billion with earnings of up to US\$ 2 trillion. UNWTO forecasted that by 2030 there will be 1.8 billion international tourism arrivals annually.

As one of the largest industries in the world, tourism is continually growing and tourism receipts are "of critical important to many countries' balances of payments and general economic welfare" Natsios[33]. It has been widely acknowledged that economic benefits arising from the tourism industry such as an increase in foreign exchange earnings, employment and income generation can overcome many resource problems as well as create opportunities and improve the quality of life of local populations, UNEP [32]. Locations which can identify and market a tourism product, whether it be a special natural, historical or cultural attraction or an urban or rural destination, can take advantage of this market by attracting revenue from visitors, Hayah; Meltem [27]. Tourism can be a focus for local economic development tied into the maintenance of the bio-physical environment. Tourism is often "used as a tool to stimulate marginal economics and to promote development through the jobs and income that it can foster". Such factors are critically important to developing countries in general and African countries in particular with much emphasis on Regional and domestic tourism development for countries as domestic tourism accounts for approximately $80 \%$ of all tourism activity worldwide. Due to people's perceptions of tourism in developing nations, priority is till given to international tourism often at the expense of the domestic tourism as the promotion and progression of tourism in developing countries been slow with less considerable role in tourism planning and development, Stephen; Gets[24]. The main motivations for domestic tourism in developing countries including visiting friends, leisure travel, business, and religious pilgrimages, Sue[26]. Mass domestic tourism motivated by leisure purposes, however, "is a more recent phenomenon related mostly to economic growth and consequent expansion of the urban middle classes", Ghimire [22].

The gains of tourism are ploughed back into the development of areas where they are generated as tourism has the ability to flourish any region or communities that have been considered "unattractive or hostile" environment. The ability of the industry to develop poorer areas from which it's generated has been a significant benefit for many communities. According to Ankomah and Crompton[6] tourism can validate traditional culture and help local people see some value in preserving and restoring historical artefacts and cultural traditions, bringing a sense of pride to the people of the host community. Therefore, tourism can be seen as a composite phenomenon which embraces the incidence of a mobile population of travelers who are strangers to the place they visit. It is essentially a pleasure activity in which money earned in one's normal domicile is spent on the place visited. Godwin [15] sees tourism as the only sector where the good at the point of production remain, at the point of sale and additionally it affords several buyers the opportunity to buy the same product over and over again. Mclntosh and Gupta [18] again defined tourism as "the sum of the phenomena and relationships arising from the interaction of tourists, business, host government and host communities in the process of attracting and hosting these tourists and other visitors". Oxford English Dictionary defines the tourist as one who travels for pleasure or culture, visiting a number of places for their objects of interest, scenery or the like.

\section{The Study Area}

Ikogosi warm spring resort is a tourism center where warm and cold springs meet at a point and flowing side by side on the same parcel of land with each retaining is thermal identities. Ikogosi warm spring is located in Ikogosi Ekiti, Ekiti west local Government area of Ekiti State, Nigeria and lies about $2 \mathrm{~km}$ west of Ikogosi town on longitude $4^{0} 56.46^{0} \mathrm{E}$ and latitude $7^{0} 36.88^{\circ} \mathrm{N}$, Abel; Abraham[1, 2]. Ikogosi Warm spring is about $55 \mathrm{~km}$ from Akure, the Ondo State capital and about $30 \mathrm{~km}$ from Ado-Ekiti, the Ekiti State Capital. It is situated between lofty, steep-sided and heavily wooded, north-south trending hills about $27.4 \mathrm{~km}$ east of Ilesha (Osun State) and about $10.5 \mathrm{~km}$ southeast of Efon Alaye (Ekiti State), figure 1.1 is a map that shows the study area. 


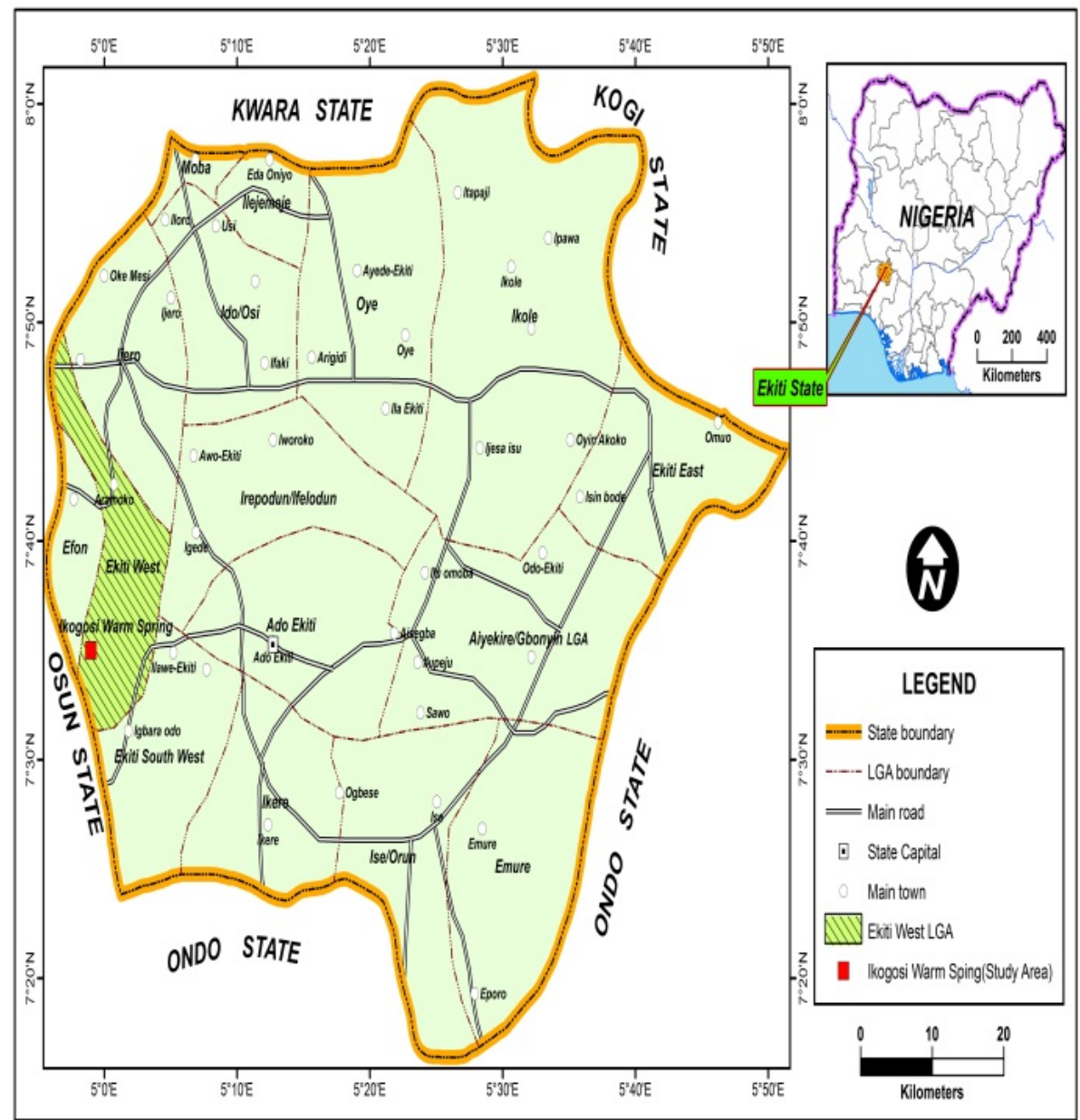

Figure 1.1. Ikogosi warm spring area, Ekiti State

The evergreen tall trees surrounding the spring provide coverage and rich vegetation is closely mined and protected from arbitrary deforestation. The tree around each flows characterized the attribute of both cold and warm springs that is whitish and brownish respectively. It is highly protected from erosion by tall and evergreen trees, the tree also serve as a sort of canopy under which tourists could stay during the dry season and sunny days. The whole environment of the spring has been deliberately left unhampered with, for ecotourism appeal while the source of the warm spring has been provided with a viewing structure for easy spotting tourists. The unique quality of the Ikogosi warm spring is its acclaimed curative power of nature's gift to mankind and it is known as one of the seven wonders in Nigeria. Therefore, Ikogosi town has been catapulted to national and international limelight because of the unique presence of the warm and cold springs. The warm spring produces signal of smoke and kind of roaring noise to alert the people of Ikogosi community in case of any approaching external aggression. It serves as a tourist attraction for the community whereby tourists visit for different purposes.

\section{Materials and Methods}

Perception in a simple sense is a process by which we become aware of certain change especially through hearing and sight Afolabi, [3] base on these two occurrences, perceiving events that are happening around us and the distributions of socio-economic activities in either our surroundings or distant places. For someone to perceive things or view locations correctly, the person must be familiar with all the information and the important of a place or a location. Johnston [36] defined perception as an agent's subjective experiential evaluation of the phenomenal which surrounds man, revealing man consciousness of it and intentionality towards the object which constitute it. Primary data were carried out this study with the aid of structured questionnaire from the host community for 300 respondents' sample size which amounted to $3 \%$ of the community projected population figure for 2005 which was $(10,215)$. Information was sought pertaining to the demographic characteristics of the respondents and the impacts of the tourist attraction on the host community both the positive and the negative aspects respectively. Ten measures were used to ascertain the respondent's perception, five for negative impact which center on: tourism has brought about inflation in property values; tourism has increased transport system cost; tourism has brought about the neglect of non-tourist recreation facilities; tourism has increased the crime rate within the community; tourism has brought natural, political 
and public relation calamities and five for positive impact on: tourism boosts economic sector of the community by improving tax revenues for government; tourism prompts social interaction within the host community; tourism creates more employment opportunities for the community; tourism creates investments for the community and lastly tourism has improved housing condition in the community. Questionnaire were distributed along the host community major streets (Ilaro- $1 \mathrm{~km}$, Erigbe- $2 \mathrm{~km}$, Idogbo- $3 \mathrm{~km}$, Ilajumu-4km and Okelele-5m) to dwellers from age 18years and above through random sampling based on availability. The host Community's evaluated their perceptions on the impacts of Ikogosi warm spring, Ekiti State towards the development of the tourist attraction by rating their level of agreement with each of the statement on a five-point Likert's scale from strongly agree (SA), agree (A), undecided (U), Disagree (D) and strongly disagree (SD). Data were analyzed and tested using descriptive and inferential statistical techniques, independent sample t- test and one-way ANOVA test at $\mathrm{p}<0.05$.

The impacts of tourism on host communities in general have been researched from a range of perspectives, Bishna; Sajad; Paul[19] and in a variety of contexts, early studies on impacts tended to focus on the positive effects of tourism on host communities, such as the economic benefits of tourism, Mathieson and Wall[18]. However, as the negative implications of tourism became increasingly evident, an alternative and more critical view of tourism impacts was taken in many studies, Cohen [11]. Studies have found that communities are not fixed in their perceptions and attitudes towards impacts, nor individuals within these communities likely to share identical attitudes towards tourism, Williams and Lawson [37]. Perceptions of tourism impacts demonstrated that perceptions and attitudes change over time Baum [7]. Androitis;Dyer;Harril;Pfister and Duarte; Yasong [5-28] examined the relationship between socio-economic and demographic attributes of local residents and their attitudes towards tourism development in Washington. Residents' attitudes toward tourism were measured by adopting 20 items from the tourism impact, factor analysis was use to analyzed the data collected. Findings supported that educating local residents about the potential benefits of tourism is critical in obtaining resident support for tourism, enhancing their involvement in the industry and achieving sustainable community development. The study reinforced the need for further research on factors influencing residents' attitude toward tourism during a destination's preliminary development stage. Brunt and Courtney [39] investigated community perceptions of the sociocultural impacts of tourism and academic writers' findings showed that perceived impacts reported by information coincided with the majority of those identified in the literature.

Nuray [23] evaluated the impacts of tourism as perceived by the residents of Safranbou with consistent positive impacts; Enemuo and Oyinkansola [13] examined the impacts of tourism development on host communities of
Osun Osogbo sacred grove in Osun State, Nigeria. The findings of the analyzed proved that tourism development had significant effect on the social life of the host communities. The study encourages public participation to be put into consideration by tourism developers and planners to ensure the sustainability of tourism development in the communities. Mansour and Mahin [17] identified the role of tourism as an element of community enrichment, as a means of meeting different cultures, maintenance of a natural environment, creating or maintaining national parks or other protected areas. They also, informed the tourism sector as the only service sector that provides concrete and quantified trading opportunities for all nations, regardless of their level of development. Bruny [38] investigated Island community perceptions of tourism development and impacts using social exchange and social representations theories. The research highlights the need for community inclusion and consultation in sustainable Island tourism policy and planning both to facilitate the process of sustainable development and to educate communities of the likely consequences. Prabha [21] investigated the resident attitudes toward tourism development in Mauitius, Socio-cultural and economic impacts had significant and positive influence on tourism development while environment impacts had a negative influence on tourism development and future tourism growth. The data for this study were collected from the primary source.

\section{Concept of Sustainable Tourism Development}

Sustainable development evolves from maintaining natural resources for present future generations to emphasizing values associated with cultural and community diversity, concern for social justice and fairness, and a strong orientation towards stability (Ahn et al, 2002). Sustainable development has, as a result been applied to tourism, particularly tourism that relies on natural resources and involves human beings and their cultures. The concepts of sustainable development is important because most tourism development, involving stakeholders such as tourists, tourists business and community residents, depends on attractions and activities related to the natural environment, heritage and culture. The World Trade Organization - W T $\mathrm{O}[45]$ define sustainable tourism development as that which meets the needs of the present tourists and host region while protecting and enhancing opportunity for the future. It is envisaged as leading management of all resources in a way of economic, social, cultural and aesthetic fulfillment thus, harnessing tourism without affecting ecological component. The Eastern Caribbean State defined sustainable tourism development as, "the Optimal use of natural and cultural resources for national development on an equitable and self-sustainable basis to provide a unique visitor experience, and an improved quality of life through partnership among government, the private sector and communities" (Canada Jamaica Green Fund, 2006). 
Hunter [44] defined sustainable tourism as an orientation towards stability. Sustainable tourism development has as a result, meeting the need and wants of the local host community in terms of improved living standard and quality life, satisfy the demand of tourist and the tourism industry, and continue to attract them in order to meet the first aim. In the widest and probably most realistic sense sustainable tourism tries to achieve a balanced relationship between (a) the environmental Impacts, (b) the sociocultural impacts and (c) the economic impacts of tourism. The notion of sustainable tourism is however often associated with alternative development', which conceives development as a bottom-up, self-reliant, environmentally sound, equitable people-centred, participatory and locally focused process.

It is therefore necessary to have rightful perceptions of the tourist center in order to sustain it. Since every economic development carry with it impact for social structures and cultural aspect of host Community Cooper;Fletcher;Gilbert;Wanhill[43]. And this would translate to increased contribution towards Gross Domestic Product, employment generation, improved economic and social progress within Community and Nigeria as a whole. As a result, people's perceptions of their immediate environment is so expedient as environmental sustainability seem as a condition of balance, resilience and interconnected that allows human society to satisfy its needs while neither exceeding the capacity of its supporting ecosystem to continue to regenerate the service necessary to meet those needs.

\section{Results and Discussion}

The demographic and socio-economic variables identified with the respondents based on sex, age, marital status, religion, educational qualification, estimated income and occupation of the respondents'.

Table 1.1. Demograhic and Socio-economic Characteristics of Respondents.

\begin{tabular}{|c|c|c|c|c|}
\hline $\mathrm{S} / \mathrm{N}$ & \multicolumn{2}{|c|}{ CHARACTERISTICS } & FREQUENCY & PERCENTAGE \\
\hline 1 & \multirow[t]{2}{*}{ SEX } & $\begin{array}{l}\text { Male } \\
\text { Female }\end{array}$ & $\begin{array}{l}130 \\
170\end{array}$ & $\begin{array}{l}56.7 \\
43.3\end{array}$ \\
\hline & & Total & 300 & 100 \\
\hline 2 & \multirow[t]{2}{*}{ AGE } & $\begin{array}{c}<30 \text { years } \\
30-40 \text { years } \\
41-50 \text { years } \\
51-60 \text { years } \\
\text { Above 60years }\end{array}$ & $\begin{array}{c}164 \\
60 \\
42 \\
22 \\
12 \\
\end{array}$ & $\begin{array}{l}54.7 \\
20.0 \\
14.0 \\
7.3 \\
4.0 \\
\end{array}$ \\
\hline & & Total & 300 & 100 \\
\hline 3 & MARITALSTATUS & $\begin{array}{c}\text { Single } \\
\text { Married } \\
\text { Divorced } \\
\text { Widowed }\end{array}$ & $\begin{array}{c}120 \\
160 \\
8 \\
12\end{array}$ & $\begin{array}{c}40.0 \\
53.6 \\
2.7 \\
4.0\end{array}$ \\
\hline \multirow[b]{2}{*}{4} & & Total & 300 & 100.0 \\
\hline & RELIGION & $\begin{array}{l}\text { Christianity } \\
\text { Islam } \\
\text { Tradition }\end{array}$ & $\begin{array}{c}240 \\
49 \\
11\end{array}$ & $\begin{array}{c}80.0 \\
16.3 \\
3.7 \\
\end{array}$ \\
\hline \multirow[b]{2}{*}{5} & & Total & 300 & 100.0 \\
\hline & $\begin{array}{c}\text { EDUCATION } \\
\text { QUALIFICA-TION }\end{array}$ & $\begin{array}{c}\text { No formal Education } \\
\text { Adult Education } \\
\text { Primary } \\
\text { Secondary } \\
\text { Tertiary } \\
\text { Other specify }\end{array}$ & $\begin{array}{c}21 \\
12 \\
12 \\
182 \\
67 \\
6 \\
\end{array}$ & $\begin{array}{c}7.0 \\
4.0 \\
4.0 \\
60.7 \\
22.7 \\
2.0 \\
\end{array}$ \\
\hline \multirow[b]{2}{*}{6} & & Total & 300 & 100 \\
\hline & ESTIMATED INCOME & $\begin{array}{c}<20,000 \\
20,000-50,000 \\
50,001-100,000 \\
100,001-200,000 \\
>200,000 \\
\end{array}$ & $\begin{array}{c}101 \\
64 \\
16 \\
5 \\
3 \\
\end{array}$ & $\begin{array}{c}53.4 \\
33.9 \\
8.5 \\
2.6 \\
1.6 \\
\end{array}$ \\
\hline \multirow[b]{2}{*}{7} & & Total & 189 & 100 \\
\hline & \multirow[t]{2}{*}{ OCCUPATION } & $\begin{array}{c}\text { Farming } \\
\text { Artisan } \\
\text { Civilservant } \\
\text { Trader } \\
\text { Student } \\
\text { OTHER SPECIFY }\end{array}$ & $\begin{array}{c}157 \\
46 \\
19 \\
36 \\
32 \\
10 \\
\end{array}$ & $\begin{array}{c}52.3 \\
15.3 \\
6.3 \\
12.0 \\
10.7 \\
3.3 \\
\end{array}$ \\
\hline & & Total & 300 & 100 \\
\hline
\end{tabular}

Source: Authour's Analysis, 2016 
Table 1.1, shows the summary of the demographic and socioeconomic characteristics of respondents in relation to impacts of tourist attraction on the individual and on the community. The sex of the community indicates that female has the highest number of respondents than male, from the 300 respondents 170 were female $(56.7 \%)$ while 130 were male (43.3\%). The age distribution also indicates majority of the respondents were in the age group less than 30years $164(54.7 \%)$. They were followed by the age group between $30-40$ years $60(20.0 \%)$. Age group 41-50years accounted for $42(14.0 \%), 51-60$ years as $22(7.3 \%)$ and those above 60 years were amounted to $12(4 \%)$. This implies that most respondents were relatively young adults. The frequency analysis for marital status of the respondents shows $160(53.6 \%)$ that were married, $120(40 \%)$ single, $8(2.7 \%)$ divorced while widowed amounted to $12(4.0 \%)$ respondents. In addition, the religion of the community shows that Christians constitute a significant proportion of respondents, $240(80.0 \%)$ were Christians, Islam also were $49(16.3 \%)$ respondents while there were no adherents of the traditional religion as only $11(3.7 \%)$ of the respondents associated with traditional religion. It is evident that basic education is associated with the community. As most of the respondents were secondary school holders of $182(60.7 \%)$, followed by tertiary education $67(22.3 \%)$, no formal education were 21 (7.0\%) respondents, adult education and primary education equal $12(4.0 \%)$ and other specify were $6(2 \%)$ respondents. Furthermore, from the response of the community, 101(53.4\%) earn less than $\# 20,000,64(33.9 \%)$ earn between $\# 20,000$ and $\# 50,000.16(8.5 \%)$ earn between $\# 50,001$ and $\# 100,000,5(2.6 \%)$ earn between $\# 100,001$ and \#200,000, while 3(1.6\%) earn above $\# 200,000$. The low income earner has the highest frequency.

There are probable explanations for this odd result. Firstly, some of the respondents refused to disclose their monthly income. As a result, no responses were considered as zero income. Secondly, Nigeria of which Ikogosi is a part is faced with the problem of unemployment and most people now engaged in Artisan and they keep no records for monthly income mostly. Clearly, from the response in table 1.1, majority of the respondents engaged in farming were $157(52.3 \%)$ in number, artisans were 46(15.3\%), Civil servant amount $19(6.3 \%)$, trader accounted for $36(12.0 \%)$, students were $32(10.7 \%)$ and other specify were $10(3.3 \%)$. Therefore, farming happened to have the highest frequency, this signifies that majority of the dwellers in the community engaged in farming activities.

Table 1.2. Respondent's Perceptions of Negative Impact on the Host Community's.

\begin{tabular}{|c|c|c|c|c|}
\hline $\mathbf{S} / \mathbf{N}$ & MEASURE & RESPONSE & FREQUENCY & PERCENTAGE \\
\hline 1 & $\begin{array}{c}\text { Tourism has brought about inflation in property } \\
\text { values. }\end{array}$ & $\begin{array}{c}\text { SA } \\
\text { A } \\
\text { U } \\
\text { D } \\
\text { SD }\end{array}$ & $\begin{array}{c}74 \\
111 \\
55 \\
42 \\
18 \\
\end{array}$ & $\begin{array}{c}24.7 \\
37.0 \\
18.3 \\
14.0 \\
6.0 \\
\end{array}$ \\
\hline & & TOTAL & 300 & 100.0 \\
\hline 2 & Tourism has increased transport system cost. & $\begin{array}{c}\text { SA } \\
\text { A } \\
\text { U } \\
\text { A } \\
\text { SA }\end{array}$ & $\begin{array}{c}60 \\
116 \\
64 \\
52 \\
8 \\
\end{array}$ & $\begin{array}{c}20.0 \\
38.7 \\
21.3 \\
17.3 \\
2.7\end{array}$ \\
\hline & & TOTAL & 300 & 100.0 \\
\hline 3 & $\begin{array}{c}\text { Tourism has brought about the neglect of } \\
\text { non-tourist recreation facilities. }\end{array}$ & $\begin{array}{c}\text { SA } \\
\text { A } \\
\text { U } \\
\text { A } \\
\text { D }\end{array}$ & $\begin{array}{c}43 \\
71 \\
67 \\
103 \\
16 \\
\end{array}$ & $\begin{array}{c}14.3 \\
23.7 \\
22.3 \\
34.3 \\
5.3\end{array}$ \\
\hline & & TOTAL & 300 & 100.0 \\
\hline 4 & $\begin{array}{l}\text { Tourism has increased the crime rate within the } \\
\text { community }\end{array}$ & $\begin{array}{c}\text { SA } \\
\text { A } \\
\text { U } \\
\text { D } \\
\text { SD }\end{array}$ & $\begin{array}{c}27 \\
69 \\
39 \\
123 \\
42 \\
\end{array}$ & $\begin{array}{c}9.0 \\
23.0 \\
13.0 \\
41.0 \\
14.0 \\
\end{array}$ \\
\hline & & Total & 300 & 100.0 \\
\hline 5 & $\begin{array}{l}\text { Tourism has brought natural, political and public } \\
\text { relation calamities.. }\end{array}$ & $\begin{array}{c}\text { SA } \\
\text { A } \\
\text { U } \\
\text { D } \\
\text { SD }\end{array}$ & $\begin{array}{c}33 \\
59 \\
62 \\
112 \\
34 \\
\end{array}$ & $\begin{array}{l}11.0 \\
19.7 \\
20.7 \\
37.3 \\
11.3 \\
\end{array}$ \\
\hline & & Total & 300 & 100.0 \\
\hline
\end{tabular}

Source: Authour's Analysis, 2016 
Table 1.2: gives an explanation on people's perceptions of the negative impacts of the tourist attraction on the community. The result of the impact on tourism has brought about inflation in property values as presented below; 74 $(24.7 \%)$ of the respondents were strongly agreed, 111 $(37.0 \%)$ agreed, 55 (18.3\%) undecided, 42 (14.0\%) disagreed while $18(6.0 \%)$ strongly disagreed. The study also reveal responses on tourism has increased transport system cost in this order, $60(20.0 \%)$ of the respondents were strongly agreed, $116(38.7 \%)$ of the respondents agreed, 64 (21.3\%) undecided, 52 (17.3\%) of the respondents disagreed while $18(2.7 \%)$ were strongly disagreed. This however implies that tourism has brought about inflation in property values on the community. On the basic of people's perceptions on if tourism has brought about the neglect of non-tourist recreation facilities, the study indicates that, 43 $(14.3 \%)$ of the respondents asserted strongly agreed, 71 (23.7\%) agreed, 67 (22.3\%) undecided, 103 (34.3\%) disagreed while $16(5.3 \%)$ strongly disagreed. This result shows that tourism has not actually brought about the neglect of non-tourist recreation facilities. The result of respondents on tourism has increased the crime rate within the community shows that, $27(0.9 \%)$ of the respondents were strongly agreed, $69(23.0 \%)$ agreed, $39(13.0 \%)$ were undecided, $123(41.0 \%)$ of the respondents disagreed while $42(2.7 \%)$ of the respondents were strongly disagreed. This shows that tourism has not increased the crime rate within the community. Also the people's perceptions on tourism has brought natural, political and public relation calamities results shows $33(11.0 \%)$ of the respondents were strongly agreed, 59 (19.7\%) agreed, 62 (20.7\%) were undecided, 112 $(37.3 \%)$ disagreed while $34(11.3 \%)$ of the respondents were strongly disagreed.

Table 1.3. Independent sample T- test for Sex on Negative Impact

\begin{tabular}{|c|c|c|c|c|c|c|}
\hline Sex & $\mathrm{N}$ & Mean & Std. Deviation & $\mathrm{t}$ & $\mathrm{df}$ & Sig. \\
\hline MALE & 130 & $\begin{array}{c}24.892 \\
3\end{array}$ & 5.94711 & \multirow{2}{*}{854} & 298 & .394 \\
\cline { 1 - 5 } $\begin{array}{c}\text { FEMA } \\
\text { LE }\end{array}$ & 170 & $\begin{array}{c}24.229 \\
4\end{array}$ & 7.16503 & & \\
\hline
\end{tabular}

Source: Authour's Analysis, 2016

The variations in people's perceptions in related to sex were subjected to Independent Samples T-Test. The result shows that there is no significant variation in people's perceptions of negative impact of tourist attraction on the community based on Sex $(\mathrm{t}=-854, \mathrm{df}=298$, sig $=0.394)$.

Where $t$ value $=854$

Degree of freedom $=298$

Significant level $=0.394$.

Table 1.4 shows the summary of ANOVA of people's perceptions of the negative impacts of the tourist attraction, such as age, marital status, religion, estimated income and occupation showed that there is no significant variation in people's perception of tourist attraction on the community except educational qualification that shows there is a significant variation in people's perception of tourist attraction on the community.

Table 1.4. ANOVA Test of People's Perception of Negative Impacts of the Tourist Attraction on the Community.

\begin{tabular}{|c|c|c|c|c|c|c|c|}
\hline Issue & $\mathrm{N}$ & Mean & Std. Deviation & & Df & $\mathrm{F}$ & Sig. \\
\hline AGE & 300 & 24.5167 & 6.66216 & Between Groups & $\begin{array}{c}4 \\
295\end{array}$ & .699 & .593 \\
\hline MARITAL STATUS & 300 & 24.5167 & 6.66216 & Within Groups & $\begin{array}{c}3 \\
296\end{array}$ & .178 & .911 \\
\hline RELIGION & 300 & 24.5167 & 6.66216 & Total & $\begin{array}{c}2 \\
297\end{array}$ & .090 & .914 \\
\hline EDUCATION & 300 & 24.5167 & 6.66216 & & $\begin{array}{c}5 \\
294\end{array}$ & 3.188 & .008 \\
\hline INCOME & 189 & 24.0529 & 7.24329 & & $\begin{array}{c}4 \\
184 \\
\end{array}$ & .667 & .616 \\
\hline OCCUPATION & 300 & 24.5167 & 6.66216 & & $\begin{array}{cc}5 \\
294 \\
\end{array}$ & 1.377 & .233 \\
\hline
\end{tabular}

Source: Authour's Analysis, 2016 
Table 1.5. People's Perceptions of Positive Impacts of Tourist Attraction on the Community.

\begin{tabular}{|c|c|c|c|c|}
\hline $\mathrm{S} / \mathrm{N}$ & MEASURE & RESPONSE & FREQUENCY & PERCENTAGE \\
\hline \multirow[t]{2}{*}{1} & $\begin{array}{l}\text { Tourism boosts economic sector of the community by } \\
\text { improving tax revenues for government }\end{array}$ & $\begin{array}{c}\text { SA } \\
\text { A } \\
\text { U } \\
\text { D } \\
\end{array}$ & $\begin{array}{c}186 \\
101 \\
10 \\
3 \\
\end{array}$ & $\begin{array}{c}62.0 \\
33.7 \\
3.3 \\
1.0 \\
\end{array}$ \\
\hline & & TOTAL & 300 & 100.0 \\
\hline \multirow[t]{2}{*}{2} & $\begin{array}{l}\text { Tourism prompts social interaction within the host } \\
\text { community. }\end{array}$ & $\begin{array}{c}\text { SA } \\
\text { A } \\
\text { U } \\
\text { A } \\
\text { SA }\end{array}$ & $\begin{array}{c}103 \\
190 \\
4 \\
2 \\
1 \\
\end{array}$ & $\begin{array}{c}34.3 \\
63.3 \\
1.3 \\
0.7 \\
0.3 \\
\end{array}$ \\
\hline & & TOTAL & 300 & 100.0 \\
\hline \multirow[t]{2}{*}{3} & $\begin{array}{l}\text { Tourism creates more employment opportunities for } \\
\text { the community. }\end{array}$ & $\begin{array}{c}\text { SA } \\
\text { A } \\
\text { U }\end{array}$ & $\begin{array}{c}138 \\
157 \\
5\end{array}$ & $\begin{array}{c}46.0 \\
52.3 \\
1.7\end{array}$ \\
\hline & & TOTAL & 300 & 100.0 \\
\hline \multirow[t]{2}{*}{4} & Tourism creates investments for the community & $\begin{array}{c}\text { SA } \\
\text { A } \\
\text { U } \\
\text { D } \\
\text { SD }\end{array}$ & $\begin{array}{c}128 \\
127 \\
33 \\
9 \\
3 \\
\end{array}$ & $\begin{array}{c}42.7 \\
42.3 \\
11.0 \\
3.0 \\
1.0 \\
\end{array}$ \\
\hline & & TOTAL & 300 & 100.0 \\
\hline \multirow[t]{2}{*}{5} & $\begin{array}{l}\text { Tourism has improved housing condition in the } \\
\text { community. }\end{array}$ & $\begin{array}{c}\text { SA } \\
\text { A } \\
\text { U } \\
\text { D } \\
\text { SD }\end{array}$ & $\begin{array}{c}97 \\
190 \\
5 \\
5 \\
2 \\
\end{array}$ & $\begin{array}{c}32.3 \\
63.3 \\
1.7 \\
2.0 \\
0.7 \\
\end{array}$ \\
\hline & & Total & 300 & 100.0 \\
\hline
\end{tabular}

Source: Authour' Source: Authour's Analysis, 2016

Table 1.5: provide details explanation on people's perceptions of the positive impacts of the tourist attraction on the community. The result of the impact on tourism boosts economic sector of the community by improving tax revenues for government shows that $186(62.0 \%)$ of the respondents were strongly agreed, $101(33.7 \%)$ agreed, 10 (3.3\%) undecided while $3(1.0 \%)$ disagreed. This indicates that government usually generates revenue through tourism development. The study also reveals response on tourism prompts social interaction within the host community, 103 $(34.3 \%)$ of the respondents were strongly agreed, 190 $(63.3 \%)$ of the respondents agreed, $4(1.3 \%)$ undecided, 2 $(0.7 \%)$ of the respondents disagreed while $1(0.3 \%)$ were strongly disagreed. This however implies that tourism prompts social interaction within the host community. People's perceptions on tourism creates more employment opportunities for the community indicates that, 138 (46.0\%) of the respondents asserted strongly agreed, $157(52.3 \%)$ agreed, 5 (1.7\%) undecided while no response for disagreed and strongly disagreed. This result shows that tourism has creates more employment opportunities for the community. The result of respondents on tourism creates investments for the community shows that, $128(42.7 \%)$ of the respondents were strongly agreed, $127(42.3 \%)$ agreed, $33(11.0 \%)$ were undecided, $9(3.0 \%)$ disagreed while $3(1.0 \%)$ strongly disagreed. This shows that tourism has created investments for the community. Also the people's perceptions on tourism has improved housing condition in the community, results shows $97(32.3 \%)$ of the respondents were strongly agreed, $190(63.3 \%)$ agreed, $5(1.7 \%)$ were undecided, 5 (2.0\%) disagreed while $2(0.7 \%)$ of the respondents were strongly disagreed. This implies that tourism has improved housing condition in the community.

Table 1.6. Independent sample $T$ - test for Sex on Positive Impact

\begin{tabular}{|c|c|c|c|c|c|c|}
\hline Gender & $\mathrm{N}$ & Mean & $\begin{array}{c}\text { Std. } \\
\text { Deviation }\end{array}$ & $\mathrm{t}$ & $\mathrm{df}$ & Sig. \\
\hline MALE & 130 & 18.9154 & 3.83180 & \multirow{2}{*}{-.646} & 298 & .519 \\
\hline FEMALE & 170 & 19.2059 & 3.88274 & & & \\
\hline
\end{tabular}

Source: Authour's Analysis, 2016

Table 1.6 shows that there is no significant variation in people's perceptions of positive impact of tourist attraction on community based on $\operatorname{Sex}(\mathrm{t}=-0.646, \mathrm{df}=298, \mathrm{p}=0.519)$.

Where $\mathrm{t}$ value $=-0.646$

$\mathrm{df}=298$

Significant level $=0.519$ 
Table 1.7. ANOVA Test of People's Perception of Positive Impacts of the Tourist Attraction on the Community.

\begin{tabular}{|c|c|c|c|c|c|c|c|c|}
\hline Issues & $\mathrm{N}$ & Mean & Std. Deviation & & Df & $\begin{array}{c}\text { Mean } \\
\text { square }\end{array}$ & $\mathrm{F}$ & Sig. \\
\hline AGE & 300 & & & $\begin{array}{c}\text { Between } \\
\text { Groups }\end{array}$ & $\begin{array}{c}4 \\
295\end{array}$ & 18.196 & 1.227 & .299 \\
\hline MARITAL STATUS & 300 & 19.0800 & 3.85701 & Within Groups & $\begin{array}{c}3 \\
296\end{array}$ & 13.184 & .885 & .449 \\
\hline RELIGION & 300 & 19.0800 & 3.85701 & Total & $\begin{array}{c}2 \\
297\end{array}$ & 30.530 & 2.067 & .128 \\
\hline EDUCATION & 300 & 19.0800 & 3.85701 & & $\begin{array}{c}5 \\
297\end{array}$ & 19.420 & 1.312 & .259 \\
\hline INCOME & 189 & 18.8783 & 3.63655 & & $\begin{array}{c}4 \\
184\end{array}$ & 13.928 & 1.054 & .381 \\
\hline OCCUPATION & 300 & 19.0800 & 3.85701 & & $\begin{array}{c}5 \\
294\end{array}$ & 27.494 & 1.875 & .099 \\
\hline
\end{tabular}

Source: Authour's Analysis, 2017.

Table 1.7 depicts the summary of ANOVA test on people's perceptions of the positive impacts of the tourist attraction in related to age, marital status, religion and educational qualification, income and occupation showed that there is no significant in variation people's perception of tourist attraction on the community.

\section{Conclusion and Recommendation}

In conclusion, the demographic and socioeconomic characteristics of the respondents, the analysis indicates that the majority of the respondents were below age 30years and Christianity religion constitute a significant proportion in the community. Furthermore, most of the respondents refused to declare their monthly income and they engaged in farming activities and majorities of the respondents have basic education with secondary school leaving certificate. Therefore, the tourism impacts can there be categories into three parts namely socio-cultural impact, economic impact and environmental impact with lists numbers of multiplier effects of tourism such as job creation, increasing income of local economy, boosting local business, generating other industrial activities in the town, social event in the community, better local facilities and infrastructure, conservation of the natural endowment and attractive environment appeals to tourists. This means that the need to embrace the sustainability of tourism industry left nobody out, in developing the tourist attraction. With respect to the sustainable tourism development there is the need for the community to have rightful perceptions of the tourist center in order to sustain it. If tourism is planned well, it will be a source of opening up for the community area which will balance tourist demands, local products, cultural and natural resources. Also, community engagement and development of tourism must be given high cognizance as wrong perception and lack of community acceptance of new policy can have adverse effect on any development.

Furthermore, indigenous knowledge, community participation support for local capabilities and cultural exchange with tourists would assist in sustainable development and improve the well-being of the residents of the host community.

\section{REFERENCES}

[1] O. T. Abel, Hydrogeochemistry and Stable Isotopes: Assessment of Ikogosi Spring Waters. American Journal of Water Resources, Vol. 1, No. 3, 25-33, 2013.

[2] E. M. Abraham, Structural mapping of Ikogosi warm spring area using Aeromagnetic derivatives and Eulerdepth estimate. International Journal of Natural and Applied Science, Vol 3(2), $15-20,2014$.

[3] E. I. Afolabi, Spatial interaction with illustrations from recreation and tourism: fundamentals of human geography. Ekiti State University, Faculty of the Social Sciences, Department of geography, 2013.

[4] C. B. Anana, Global Tourism, Aph publishing corporation, 4435-36/7, Ansari road, Darya, Ganj New Delhi- 11002, 2009.

[5] K. Androitis, Vanghan, D. R. Urban Residents' Attitudes towards Tourism Development: The case of Crete. Journal of Travel Research, 42(2), 172 - 185, 2003.

[6] P. Ankomah, Crompton J. Unrealised Tourism Potential: The case of Sub-Sahara Africa. Tourism management II (1), 11-28, 1990.

[7] T. Baum, Taking the exit route: Extending the tourism life area cycle model. Current issues in Tourism 1, European Journal of Tourism Hospitality and Research. Vol.1, 167 - 175, 2008.

[8] E. Benson, Ifeyinwa D. Cultural Tourism and Sustainability in Nigeria. Department of Urban and Regional Planning, Obafemi Awolowo University, Ile-Ife, Nigeria. Mediterranean Journal of Social Sciences, MCSER Publishing, Italy, Vol 5, 2014.

[9] D. M. Brent, Bett W. and Croy W. G. Community perceptions of tourism, Bruny and Magnetic Islands Australia. Asia pacific Journal of tourism research Vol. 15, no 3, 353-366, 2010.

[10] S. Bishna, Pam D. The residents perceptions of tourism imparts: using data from the sunshine coast Australia, University of the sunshine coast Australia. Vol 10(2), 37-46, 2012.

[11] S. ChoI, Measuring Residents Attitude towards Sustainable 
Tourism: Development of Sustainable tourism Attitude Scale. School of Hospitality and Tourism Management at University of Guelph, Ontario. Journal of Travel Research Vol 43 (4) 380-394, 2005.

[12] M. Dyer, An Empirical Assessment of Residents Attitude for Sustainable Tourism Development: A case study of O'ahu, Hawaii, Journal of Sustainability and Green Business, 2007.

[13] O. B. Enemuo, Oyinkansola, O. Impacts of tourism development on host communities: Case study of Osun Osogbo sacred groved in Osun State. Journal of Humanities and Social Science, Vol.(2) 6, 30-35, 2011.

[14] Guardian Newspaper, pg 62, Wednesday November 13, 2013.

[15] H. Godwin, Community Involvement in Tourism around National parks: Opportunities and Constraints Global Ecotourism policies and Case Studies Channels, 2002.

[16] O. Harril, Residents Attitudes Tourism and Perceived Personal Be1nefits in Rural Community. Journal of Travel Research. Vol 47 (1), 84-93, 2004.

[17] E. Z. Mansour, Mahin, E. Z. The impacts of tourism industry on host community. European Journal of Tourism Hospitality and Research. Vol.1 (2), 12-21, 2013.

[18] R. W. Mclntosh, Gupta S. Tourism in Tropical Africa, Annals of Tourism Research, Vol(4), 519 - 660, 1980.

[19] L. Mathieson and Wall S. Tourism: Economic, Physical and Social Impacts, Longman, 1982.

[20] B. Paul, Paul, C. Host perceptions of sociocultural imparts. Annals of Tourism Research, Vol 26(3), 493-515, 1999.

[21] R. E. Pfister, Duarte B.M. Tourism perceptions in a climate of change. Annals of Tourism Research, Vol 37 (2), 333-354, 2010 .

[22] R. M. Prabha, Resident attitudes towards perceived Tourism benefits. University of Technology Mauritius, Social Science Research Network, 2011.

[23] R. Ghimire, Protap M. Travel and Tourism, Heinemann education publishers, Halley court, Jordan hill oxford, 2001.

[24] B. Nuray, H. Tourism and Indigenous people, International Thomson business press, Berkshire house, London, 1996.

[25] J. P. Stephen, Gets D. The business of Rural Tourism: International perspectives. Typeset by J\&L composition ltd, North Yorkshire, Uk.dson, 1997.

[26] A. E. Sajad, Mahdi, K. Perception of community in Tourism impacts and their participation in tourism planning: Ramsar, Iran. Journal of Asian behavioural studies. Vol 2. Pg 5, 2012.
[27] D. G. Sue, Ranie, P. GCSE in leisure and Tourism: Typeset by Fakenham photosetting ltd, Euston road, London, 2003.

[28] T. Hayah, Meltem, C. Tourist satisfaction: its interaction with loyalty towards a destination, Nigeria. 2007.

[29] W. Yasong, Pfister, R. E. and Mardis, D.B. Residents attitudes toward tourism development: A case study of Washington, NC deport of park, The Pennsylvania State University, 2011.

[30] Online available: http:wtdunwto.org/.../about-wtd-2014, World Tourism Day

[31] Online available: http:://evetegy.com/wtm-london-2014. World Travel Organization, 2014

[32] Online available: http://wwreinisfischer.com/ United Nation World Tourism Organization, 2014.

[33] Online available: http://books.google.com.ng/books?isbn=1317966988, United Nations Environment Pogramme, 2011.

[34] Online available: http://rmportal.net/....tourism, Andrew S. Natsios, 2004

[35] Online available: http://www.cbdint/.../tourism

[36] Online available: http://www.slideshare.net/.../tourist , Cohen 1979.

[37] Online available: http://books.google.com.ng/books? Isbn=8176255548, Johnston, 1981.

[38] Online available: maxwellsci.com/print/.../u4-863.868pdf, Williams and Lawson, 2001.

[39] Online available: epubs.scu.edu.au/.../view content.cgi? Bruny, 2012.

[40] Online available: ijbssnet.com/journals/vol_4.../6.pdf

[41] Online available: Jamica Social Investment fund, www.jsif.org, 2006.

[42] B. L. Ahn, Shafer C. S. Tourist's perceptions towards the role of stakeholders in sustainable tourism. Procedia-Social and Behavioral Sciences, Vol 144 pg 313-321, 2014.

[43] C. Cooper, Fletcher J., S. Wanhill and Gilbert S. Tourism Principle and Practice, Pearson, Harow, 1993.

[44] C. Hunter. Sustainable Tourism and the Touristic Ecological Footprint. Environment, Development and Sustainability, Vol 4 (1), pg 7-20, 2002.

[45] Online available: World Tourism Organization, www2.unwto.org/.../wto-technical 